\title{
離散写像による流体混合過程のモデル化 ${ }^{\dagger}$ 一ニューラルネットワークによる組み合わせ最適化法を用いた写像構成法一
}

\author{
虂 裕司・井上義朗 ${ }^{\dagger+}$ ・平田雄志
}

\begin{abstract}
大阪大学大学院基碟工学研究科 化学系尃攻化学工学分野，560-8531 豊中市待兼山町 1 番 3 号
速度べクトル時間的に積分することにより得られる流体粒子の位置変化から, 混合パターンの時間変 化を計算することができる.特に, 時間的に周期変動する流れ場では, 1 周期間の流体粒子の位置変化を知 るだけで，周期の整数倍となる時刻における混合パターンが予測できる．本論文では，周期的に変化する 層流場において混合過程を表現しうる新しい離散モデルを提示する．このモデルでは，独立变数（時間と 空間）と従属变数（濃度）の両方を離散化することにより, 連続的に変化する流体の運動を離散的に取り 扱い, 混合パターンの時間変化を混合パターンを表すべクトルの回転運動として表現する.1 周期間の流体 粒子の位置変化を精度よく表現するために, ニューラルネットワーク理論に基つく組み合わせ最適化法と ドメイン縮小法を組み合わせた新しいアルゴリズムを開発した．ニれにより，層流場における混合パター ンの時間変化を，高精度かつ高速に計算することが可能になった。
\end{abstract}

\section{緒晋}

均相系における流体混合は，流動と分子拡散によって起こる. 分子拡散効果が無視できる系では, 流体の流動状態がわかれば,

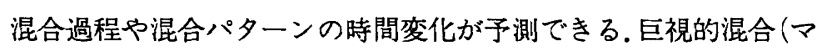
クロ混合) 現象は, 大域的あるいは時間平均的な流動状態によっ て支配され, 通常は, 混合系内のマクロな速度分布の形, 滞留時 間分布特性, 循環時間分布特性などを用いて議論される(Mann et al., 1997 ; Koh et al., 1987; Funahashi et al., 1987). 他方, 微 視的混合 (ミクロ混合) 現象には, 分子拡散だけでなく速度分布 形の微細な構造や速度変動が関与し，これらに对して様々な現象 論的モデルが提唱されてきた(Zwietering, 1984 ; Fox and Viller. maux, 1990 ; Sheikh and Vigil, 1992).

通常の混合操作は乱流条件下で行われることが多いが, 乱流場 の構造はまだ十分に解明されていないため, そこでの流体混合現 象については不明な部分が多い. 他方, 高分子の重合反応系のよ うな高粘性流体の混合は, 層流条件下で行われることが多い. 層 流は乱流に比へて解析が容易であるため, 多数の数值シミュレー ションが行われてきた（Tanguy et al., 1992）. 2枚パドル翼など の単純な形状の擋汼翼をもつ擋汼槽内の流れについては, 実測值 と計算値の一致が確かめられている (Abid et al., 1994).このよ うな摚汼槽内の層流速度分布に関する研究に比へると, 混合過程 についての理論的な解析は遅れている。

高粘性流体では, 一般に拡散係数が小さいため, 墨流し模様に 似た微細な縞模様が流動によって形成される.混合の進行は, こ れらの縞模様の変形および縞間隔の減少として現れる．実測ある いは数值シミュレーションによって得られたオイラー的な速度場 の情報をもとにして，微分方程式で表された濃度変化の式を差分 法等を用いて数值積分する通常の解析法では, 人工拡散等の影響 によって細かい縞模様を再現することが困難になる.

流れ関数が既知の流れ場では，ラグラジアン的視点から流体粒

†1999 年 12 月 2 日受理

化学工学会第 31 回秋季大会 (米沢, 1998 年 9 月) および化学工学会第 64 年会 (名古屋, 1999 年 3 月) にて発表

†† inoue@ cheng.es.osaka-u.ac.jp
子の運動を解析する非線形ダイナミクス理論を用いることにより， 微細な縞模様が形成される仕組みを説明することができる (Inoue and Hirata, 1999, 2000). また, 自己相似的なフラクタル 構造を有する微細な混合パターンや, カオス的混合による一様混 合領域と剪断的混合が支配的な不良混合領域を計算により表現す ることも可能である.

非線形ダイナミクス理論による解析は厳密かつ詳細であり, 層 流混合の解析に強力な手段を提供してくれる. 流れ関数や速度へ クトルが式の形で与えられた 2 次元流れ系の混合解析には特に有 効である. しかし, 通常の擋找槽内の流れのように, 複雑な 3 次元 流れをなし, 速度分布が閉じた式の形で与えられていない場合に は, 非線形ダイナミクス理論による解析法をそのまま適用するこ とは極めて困難である.

これらの欠点を補うものとして, 本研究では, 流体の混合過程 を離散化して取り扱う方法を提示する.混合機構の詳細なメカニ ズムに関する解析能力については, 非線形ダイナミクス理論に基 づく解析法には及ばないが, 本離散モデルは, 複雑な 3 次元流れ場 における流体混合系への拡張が容易であるばかりでなく, 混合パ ターンの時間変化の計算速度が速い等の特色を有する.また, 個々 の流体粒子のラグラジアン的な運動に立脚したモデルであるため, 微細な縞模様の混合パターンを表現することも可能である.

\section{1. 混合の離散写像モデルと头の構成法}

\section{1 混合過程の離散写像モデル}

1.1 .1 混合パターンベクトル $K$ 種類の流体種を含む均相 系における層流混合を考える. 流体の密度や粘度は流体種に依存 せず，速度場はすべての流体種に対して同じであると仮定する. 流れ系を同じ面積の $N$ 個の微小セルに分割し, 各微小七ル $i(i=$ $1,2, \cdots, N)$ に対して，i=1から $N$ までの番号を付ける（Fig. 1).混合パターンを, この微小セルサイズの空間分解能で表現す る.すなわち, 微小セル内は同一の流体種で占められ, 微小セル 内部の細かい混合パターンは考えないとする.このとき, 系内の すへてて微小セル内の流体種を指定すれば, 混合パターンが確定 する.

時刻 $\theta$ に $i$ 番目の微小セルを占める流体種を表す番号を $p_{i}$ 


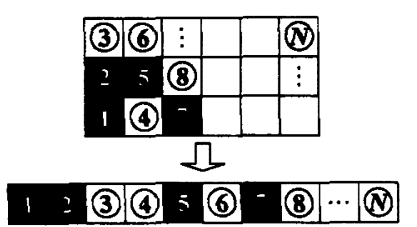

Fig. 1 One-dimensional expression of mixing pattern

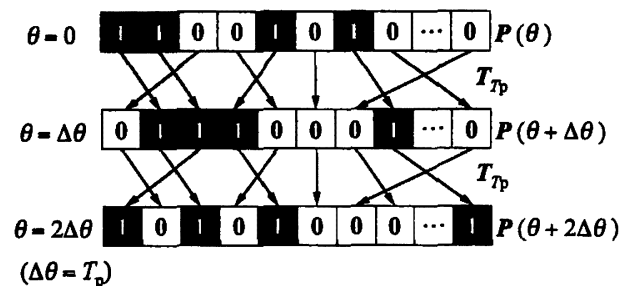

Fig. 2 Expression of mixing pattern change with discrete mapping in periodic flow

$(\theta)(i=1,2, \cdots, N)$ で表す。このとき，これらを成分とする $N$ 次 元のぺクトル $\boldsymbol{P}(\theta)$ を用いて, 混合パターンを表現することがで きる (Fig. 2)。

$$
\boldsymbol{P}(\theta)=\left(\begin{array}{c}
p_{1}(\theta) \\
p_{2}(\theta) \\
\vdots \\
p_{N}(\theta)
\end{array}\right)
$$

以後は簡略化のために, 白色と黒色の 2 種の流体種の混合を考 之るが $(K=2), K>2$ の多成分系であっても以後の取り扱いに本 質的な変わりはない. ここでは, 白色流体種の番号を 0 , 黒色流体 種の番号を 1 で表す。

1.1 .2 写像行列流動による流体の位置変化によって各微 小セルを占める流体種が変わると, 混合パターンとそれに対応す る混合パターンベクトルが変化する. 非圧縮性流体では, 白色流 体と黒色流体の面積はそれぞれ保存されるため，混合パターンべ クトルに含まれる成分 0 の数と成分 1 の数は変化しない。すなわ ち, 混合パターンの時間変化は, 混合パターンベクトルの方向変 化として表現される. $N$ 次元べクトルの方向を変える写像は, $N \times N$ の直交行列によって表現される。また，この写像は 1 対 1 の離散写像である.

時刻 $\theta$ における混合パターンベクトル $\boldsymbol{P}(\theta)$ から, $\Delta \theta$ 時間後 の混合パターンベクトル $\boldsymbol{P}(\theta+\Delta \theta)$ に写像する $N \times N$ の正方行 列を $\boldsymbol{T}_{\Delta \theta}(\theta)$ と表す. この写像行列 $\boldsymbol{T}_{\Delta \theta}(\theta) の(j, i)$ 成分 $T_{j i}$ $(\Delta \theta ; \theta) \quad(i, j=1,2, \cdots, N)$ は, 0 または 1 の值をとる 2 值変数 で, 微小七ル $i$ から微小七ル $j$ への移動があるときは 1 , それ以外 では 0 となる。微小セル間の流体移動は 1 对 1 写像であるため, 写 像行列 $\boldsymbol{T}_{\Delta \theta}(\theta)$ の各行と各列の成分には, 1 が一つだけ含まれ他は すべて0である。

この写像行列 $T_{\Delta \theta}(\theta)$ を用いると, 混合パターンの時間変化は 次式のように表現できる.

$$
\boldsymbol{P}(\theta+\Delta \theta)=\boldsymbol{T}_{\Delta \theta}(\theta) \boldsymbol{P}(\theta)
$$

流れ場が周期 $T_{\mathrm{p}}$ で変化する場合, 写像間隔を $\Delta \theta=T_{\mathrm{p}}$ とする と,

$$
\boldsymbol{T}_{\Delta \theta}(\theta)=\boldsymbol{T}_{\Delta \theta}(\theta+n \Delta \theta) \quad(n: \text { integer })
$$

となるため, $n \Delta \theta$ 時間後の混合パターンベクトル $\boldsymbol{P}(\theta+n \Delta \theta)$ は, 同一の写像行列 $\boldsymbol{T}_{T_{\mathrm{p}}}(\theta)$ を混合パターンベクトル $\boldsymbol{P}(\theta)$ に $n$ 回作用させることにより得られる (Fig. 2).

$$
\boldsymbol{P}(\theta+n \Delta \theta)=\boldsymbol{T}_{T_{\mathrm{p}}}(\theta+(n-1) \Delta \theta) \cdots \cdot \boldsymbol{T}_{T_{\mathrm{p}}}(\theta) \boldsymbol{P}(\theta)
$$

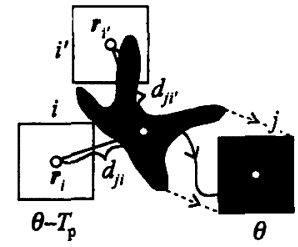

(a)

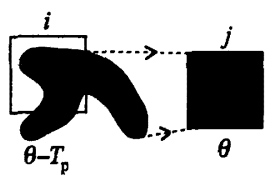

(b)
Fig. 3 Definition of (a) distance $d_{j i}$ and (b) area ratio $S_{j i}$

$$
=\boldsymbol{T}_{T_{\mathrm{p}}}{ }^{n}(\theta) \boldsymbol{P}(\theta)
$$

このように, $T_{\mathrm{p}}$ 時間間隔毎の混合状態の時間変化は, 一つの写 像行列 $\boldsymbol{T}_{T_{\mathrm{p}}}(\theta)$ のみを用いて決定することができる.

これ以降は, 初期時刻 $\theta=0$ から流れ場の 1 周期後の流体移動 を表す写像行列 $\boldsymbol{T}_{T_{\mathrm{p}}}(\theta)$ を $\boldsymbol{T}_{T_{\mathrm{p}}}$, その $(j, i)$ 成分 $T_{j i}\left(T_{\mathrm{p}} ; \theta\right)$ を $T_{j i}$ と略記する。

\section{2 ニューラルネットワーク理鯩に基つくく写像行列の決定}

流れ場が既知であれば，流体の速度べクトルをラグラジアン的 に時間積分することにより, 各微小セル内の代表点の流体粒子が 1 周期後にどの微小七ルに移動するかがわかる. 前節で導入され た写像行列 $\boldsymbol{T}_{T_{\mathrm{p}}}(\theta)$ は，このような流体粒子の移動をできるだけ 正確に表現するものではなければならない。

しかし, 系内の微小セル数 $N$ が大きい場合, 1 对 1 写像の拘束 条件と上述の条件を同時に満たすような $N$ 個の微小セルから $N$ 個の微小セルへの移動を表す写像を見出すことは極めて困難であ る. 本論文では, 微小セル間の写像の最適な組合せを見出すため に, ニューラルネットワーク理論による組み合わせ最適化法を利 用した。

1.2 .1 評価関数の設定 組合せ最適化問題では, 適当な評価 関数を設定し, 離散変数からなるその評価関数の最小值を求める ことにより，最適な組み合わせを見出す，微小セル間の最適な写 像を見出すための評価関数 $F\left(T_{j i}\right)$ を以下のように設定した.

時刻 $\theta$ に, 微小七ル $j$ の中心に存在する流体粒子に注目する. この流体粒子がどの微小セルから来たかを決めるために, 前時刻 $\theta-T_{\mathrm{p}}$ における位置 $\boldsymbol{g}_{j}$ を調へる，位置べクトル $\boldsymbol{g}_{j}$ は, 流れ場の 速度ペクトルを負の方向に時間積分することにより得られる。一 般に, 前時刻 $\theta-T_{\mathrm{p}}$ の位置 $\boldsymbol{g}_{j}$ は微小七ルの中心座標とは一致し ないため, $i$ 番目の微小セルの中心座標 $\boldsymbol{r}_{i}$ との距離 $d_{j i} \equiv\left|\boldsymbol{g}_{j}-\boldsymbol{r}_{i}\right|$ を考える (Fig. 3(a)). 系内のすへてての微小セル $i(i=1,2, \cdots, N)$ について距離 $d_{j i}$ を計算し， $d_{j i}$ のできるだけ小さい組み合わせ $(j, i)$ を選んで, それを微小セル $i$ から微小セル $j$ への流体移動を 表す写像の有力な候補とみなす，同様の計算を他のすべての微小 セル中心 $j(j=1,2, \cdots, N)$ を占める流体粒子についても行j. 系 内の各微小セル $i$ に对して, ただ 1 個の微小セル $j$ を対応させる ことにより得られる $N$ 個の $d_{j i}$ の総和が最小になる組み合わせ が, 系全体として最も好ましい組み合わせと考えられる。 $j$ を固定 したとき， $i を 1$ から $N$ まで変化させたときに $d_{j i}$ が最小となる 組み合わせ $(j, i)$ が，必ずしも系全体として見たときの最適な組 み合わせを与えないことに注意すべきである. 前時刻 $\theta-T_{\mathrm{p}}$ の流 体要素の代表位置として, 時刻 $\theta$ における微小セル $j$ の心にい た流体要素か，前時刻 $\theta-T_{\mathrm{p}}$ にいた位置ベクトル $\boldsymbol{g}_{j}$ を用いたが, その代わりに微小セルを占めている流体の前時刻 $\theta-T_{\mathrm{p}}$ におけ る重心位置を用いてもよい。

これまでは, 微小セル間の対応付けの評価基準として, 微小セ ルの代表位置間の距離だけを考えてきた，流動により，系内の各 微小セル内の流体要素は, 位置の移動だけでなく変形も受ける. 


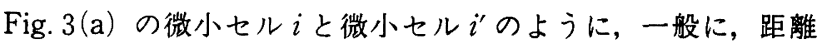
$d_{j i}, d_{j i}{ }^{\prime}$ がほぼ同じであっても, 前時刻 $\theta-T_{\mathrm{p}}$ の変形した流体要 素と微小セル $i$ や $i^{\prime}$ との重なり面積は異なる. この場合, 面積の 重なりが大きい組み合わせ（困では $i^{\prime}$ と）を優先すべきである。 時刻 $\theta$ に微小七ル $j$ を占める流体要素が, 前時刻 $\theta-T_{\mathrm{p}}$ に微小 セル $i$ を占有していた面積割合を $S_{j i}$ とする (Fig. 3(b)). 微小セ ル間の最適な対応を表す組み合わせを見出すためには, 距離因子 $d_{j i}$ だけでなく面積因子 $S_{j i}$ も考虑する必要がある.

Eq. (5) の平均距離因子 $\left(d_{j i}\right)$ ave と平均面積因子 $\left(S_{j i}\right)_{\mathrm{ave}}$ を定義 する. ただし, $H(x)$ は $x>0$ で $H=1, x \leq 0$ で $H=0$ となる階段 関数である.

$$
\begin{aligned}
&\left(d_{j i}\right)_{\mathrm{ave}} \approx \frac{\sum_{i}^{N} \sum_{j}^{N} d_{j i}}{N^{2}} \\
&\left(S_{j i}\right)_{\mathrm{ave}} \approx \frac{\sum_{i}^{N} \sum_{j}^{N} S_{j i}}{\sum_{i}^{N} \sum_{j}^{N} H\left(S_{j i}\right)}
\end{aligned}
$$

これらを用いて規格化した距離因子と面積因子をそれぞれ $d_{j i}{ }^{*}$ $\left(\equiv d_{j i} /\left(d_{j i}\right)_{\mathrm{ave}}\right)$ と $S_{j i}{ }^{*}\left(\equiv S_{j i} /\left(S_{j i}\right)_{\mathrm{ave}}\right)$ とする。重みパラメー夕 $\alpha(0 \leq \alpha \leq 1)$ を用いて, これらの因子を結合させた新しい因子 $D_{j i}{ }^{*}$ $\left(\equiv(1-\alpha) d_{j i}{ }^{*}-\alpha S_{j i}{ }^{*}\right)$ を導入する. $D_{j i}{ }^{*}$ ができるだけ小さくなる 組み合わせ $(j, i)$ が, 微小七ル $i$ から微小セル $j へ の$ 写像候補と して適当な組合せであると考える。

各微小セル $i$ には, ( $i=j$ や $i=k$ の恒等写像の場合も含めて) 必ず微小セル $i$ への流体の流入を表す写像行列の成分 $T_{i k}$ と微小 セル $i$ からの流出を表す成分 $T_{j i}$ が付随している. 写像行列の成

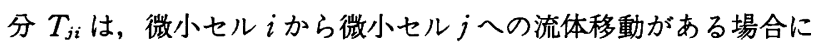
は 1 , ない場合には 0 となる 2 值変数であることを考虑して， $k \rightarrow$ $i \rightarrow j$ の 3 七ル間にわたる流体移動を写像として採用することに 対する適性度を評価する関数として次式を定義する。

$$
\sum_{i}^{N}\left\{\sum_{k}^{N} \sum_{j}^{N}\left(D_{i k}{ }^{*}+D_{j i}{ }^{*}\right) T_{i k} T_{j i}\right\}
$$

この值をできるだけ小さくするような系全体としての写像の組 み合わせを見出す必要がある. Eq. (6)のように, 評価関数を写像 行列成分 $T_{j i}$ の 2 次形式とすることによって, 2 セル間の写像の 選択が, 系内の他のすべての写像の組み合わせの評価に影響を及 ほす伝搬効果をもたせている.

また, 微小セル $i$ と微小セル $j$ との対応付けを 1 对 1 に制限し ているために, 次式の拘束条件が満たされる必要がある。

$$
\begin{aligned}
& \sum_{j=1}^{N} T_{j i}=1 \quad(i=1,2, \cdots, N) \\
& \sum_{i=1}^{N} T_{j i}=1 \quad(j=1,2, \cdots, N)
\end{aligned}
$$

以上の適合測度 Eq. (6) と拘束条件 Eq. (7) の両方を考虑して, 以下の結合的な評価関数 $F\left(T_{j i}\right)$ を定義する.

$$
\begin{aligned}
F\left(T_{j i}\right)= & A\left\{\sum_{i}^{N}\left(\sum_{j}^{N} T_{j i}-1\right)^{2}+\sum_{j}^{N}\left(\sum_{i}^{N} T_{j i}-1\right)^{2}\right\} \\
& +\sum_{i}^{N}\left\{\sum_{k}^{N} \sum_{j}^{N}\left(D_{i k}{ }^{*}+D_{j i}{ }^{*}\right) T_{i k} T_{j i}\right\}
\end{aligned}
$$

ただし， $A(A \geqq 0)$ は写像行列を 1 対 1 とする拘束条件の重み を表すパラメーターである.

1.2 .2 評価関数の最小化 評価関数 Eq. (8) を最小化する変 数の組 $T_{j i}(i, j=1,2, \cdots, N)$ を見出す手順として, ニューラルネ ットワーク理論における勾配力学系を利用する標準的手法を用い た.

本来は 0 または 1 の值をとる 2 值変数である $T_{j i}$ を, 一時的に
連続的に変化する実数と見なし，Eq. (9)の $T_{j i}$ に関する連立微分 方程式

$$
\frac{d T_{j i}}{d t}=-T_{j i}\left(1-T_{j i}\right) \frac{\partial F}{\partial T_{j i}} \quad(i, j=1,2, \cdots, N)
$$

の定常解を求めると, それらは必ず 0 または 1 の值に収斂し, 評価 関数 $F\left(T_{j i}\right)$ の極小值を与えることが, Hopfield らの解析によっ て証明されている (Hopfield and Tank, 1985).

実際に Eq. (9) を積分する際の初期值 $\left.T_{j i}\right|_{t=0}$ は, Hopfield らに ならいそれらの総和が $t=\infty$ における值 $\sum_{i}^{N} \sum_{j}^{N} T_{j i}=N$ と等しく なるように, $\left.T_{j i}\right|_{t=0}=1 / N$ と選んだ (Hopfield and Tank, 1985). 数值積分には次式の Euler 法を用いた（Uesaka, 1993).

$$
\left.T_{j i}\right|_{t+h}=\left.T_{j i}\right|_{t}-h \times f_{j i} \quad(i, j=1,2, \cdots, N)
$$
ただし

$$
\begin{aligned}
& f_{j i} \equiv\left|T_{j i}\left(1-T_{j i}\right) \frac{\partial F}{\partial T_{j i}}\right| \quad(i, j=1,2, \cdots, N) \\
& \|f\| \equiv \sqrt{\sum_{i}^{N} \sum_{j}^{N} f_{j i}{ }^{2}}, \quad h=\frac{\Delta}{\|f\|}
\end{aligned}
$$

$\Delta$ は反復計算における $t$ の増分の最大值である. Eq. (11) で実質 的な $t$ の増分 $h$ の再調整を行っていることからもわかるように, Eq. (9) 中の $t$ には時間のような物理的意味はなく, $F$ の停留値を 与之る $T_{j i}$ を求めるための単なる反復計算のパラメーターである. 収束反復計算の終了条件を $T_{j i}\left(1-T_{j i}\right)<10^{-6}(i, j=1,2, \cdots, N)$ とする。

1.2 .3 写像行列の修正 一般にニューラルネットワーク理 論を用いて計算された評価関数 $F$ の収束值は, 最小值ではなく極 小值である.よって, Eq.(9)を用いて得られた写像行列 $\boldsymbol{T}_{T_{\mathrm{p}}}$ は必 ずしも最適であるとは限らない.この傾向は微小セル数 $N$ の増加 とともに顕著になり, 評価関数 $F$ の収束解を与える $T_{j i}$ から得ら れる離散写像 $\boldsymbol{T}_{T_{\mathrm{p}}}$ の精度が低下するばかりでなく, 写像行列が 1 対 1 の拘束条件を満足しない場合もある.そのような場合, 以下の 方法で離散写像行列の修正を行った。

1 次計算で得られた収束後の写像行列の中で, 1 对 1 写像の拘束 条件を満足しなかった行と列の成分だけを取り出し，それらに新 たな初期值を設定する。この状態を初期状態として, 取り出した 写像行列の成分に対してのみ再び Eq.(9) の勾配力学系を適用し, 収束解を求める. 全ての成分が 1 对 1 の拘束条件を満足するまで この一連の操作を絽り返す。このアルゴリズムからも明らかなよ うに, 得られた修正解も評価関数 $F$ の極小解になっているだけで なく, 修正前の評価関数值よりも小さい収束值が得られる.

1.2.4 ドメイン縮小法による改良 流れ場の微小セル数 $N$ が大きくなると, 前述の評価関数の最小解が得にくいという問題 に加之, 計算時間と使用メモリーの爆発的な増加が起こるため, 最適な組合せを求める収束計算が困難になる。.そこで, 混合過程 を十分に表現し得るだけの空間分解能を与える大きな微小セル数 $N$ を用いても収束計算が可能となるように，アルゴリズムを次の ように修正した。

$N$ 個の微小セルから成る系を，まず最初に $N / 2$ 個ずつの微小 セルを含む左右 2 つグループに分け，これを時刻 $\theta-T_{\mathrm{p}}$ におけ るサブドメインとする(Fig. 4). 着目する時刻 $\theta$ における $N$ 個の 微小セルの中心位置を占める各流体粒子が, 前時刻 $\theta-T_{\mathrm{p}}$ に左右 どちらのサブドメインに属していたかを調へ，それに応して時刻

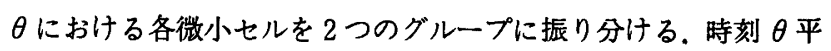
面上で, 各グループに属する微小セル数の総和が $N / 2$ からずれる 場合は, 微小セルの一部を他のグループに所属換えする必要があ 


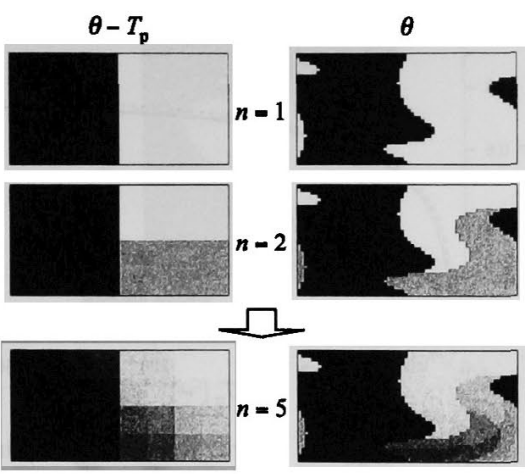

Fig. 4 Dividing flow field into sub-domains

る. その際, 時刻 $\theta-T_{\mathrm{p}}$ 平面におけるドメイン境界からの距離が 小さいものから順に所属換之を行う。これにより，着目する時刻 $\theta$ 平面上の各サブドメインを $N / 2$ 個ずつの等しい個数の微小七

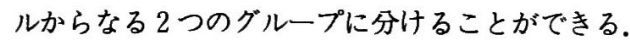

次に, 時刻 $\theta-T_{\mathrm{p}}$ 平面の各サブドメインをさらにそれぞれ上下 に2等分し，系全体として 4 個のサブドメインを作る (Fig. 4). 時刻 $\theta$ 平面における各微小七ルを占める流体が, 前時刻 $\theta-T_{\mathrm{p}}$ における 4 個のサブドメインの何れに所属していたかを，上と同 様の方法で調へる.このような操作を $n$ 回繰り返すと, 1 つのサブ ドメインに属する微小セル数は $N / 2^{n}$ に減少する.各段階で, 時刻 $\theta-T_{\mathrm{p}}$ 平面上のドメイン境界を表す直線と, 時刻 $\theta$ 平面における セルグループの境界との対応が，微小セルサイズの空間分解能で 順次決まっていく.しかし, 時刻 $\theta-T_{\mathrm{p}}$ 平面と時刻 $\theta$ 平面に扔け る，各サフドメイン内部の個々の微小七ル間の对応は未決定のま ま残される. 1 個のサフトトメインに含まれる微小セル数 $N / 2^{n}$ が ある程度小さくなった段階で (本研究では $N / 2^{n} \leq 64$ ), 各サブド メインに対して先に述へたニューラルネットワーク理諭に基づく 組み合わせ最適化法を適用して, 時刻 $\theta-T_{\mathrm{p}}$ 平面における各微小 セルと時刻 $\theta$ 平面における各微小セルとの間の 1 対 1 写像を完 成させる. 流れ系内の微小七儿数 $N$ が $2^{n}$ の場合, $N / 2^{n}=1$ とな るまで $n=\log _{2} N$ 回サフドメインの分割を行うことにより，二ュ ーラルネットワーク理論による組合せ最適化法を用いることなく 直接 1 对 1 写像を決めることも可能である.

\section{3 混合場の計算モデル}

混合の流れ場として, Fig.5のように流線が $(\mathrm{a}) \rightarrow(\mathrm{b}) \rightarrow(\mathrm{c}) \rightarrow$ $(\mathrm{d}) \rightarrow(\mathrm{a})$ の上うに周期的に変化する, 層流の 2 次元セル状对流を 考之る (Inoue and Hirata, 1999, 2000). 流れ関数 $\psi(x, z, \theta)$ は 次式で与えられる.

$$
\phi(x, z, \theta)=\psi_{0}(x, z)+\varepsilon \psi_{1}(z, \theta)
$$

ただし，

$$
\begin{aligned}
& \psi_{0}(x, z)=-\frac{1}{\pi}\left(\frac{1}{4}-z^{2}\right)^{2} \sin (\pi x) \\
& \psi_{1}(z, \theta)=-\frac{1}{2 \pi} \cos (2 \pi z) \sin (\omega \theta)
\end{aligned}
$$

$\psi_{0}(x, z)$ は定常流れを表し, $\psi_{1}(z, \theta)$ は周期 $T_{\mathrm{p}}=2 \pi / \omega$ で変動 する攝動部分， $\varepsilon$ はその振幅に関係する，また，两端点 $(x=0,2)$ に周期境界条件を課す.

Eqs. (12)，(13)から導出される速度べクトルを，4 次の RKG 法 を用いて数値積分することにより，1 周期前または後の流体粒子 の位置変化を求め, それより $d_{\boldsymbol{n}}$ を計算した，また，Eq. (5) 中の 面積因子 $S_{j i}$ は， $10 \times 10$ 個のトレーサ一粒子を微小セル $j$ 内に配 置しそれれが前時刻に微小セル $i$ に属していた個数割合より計

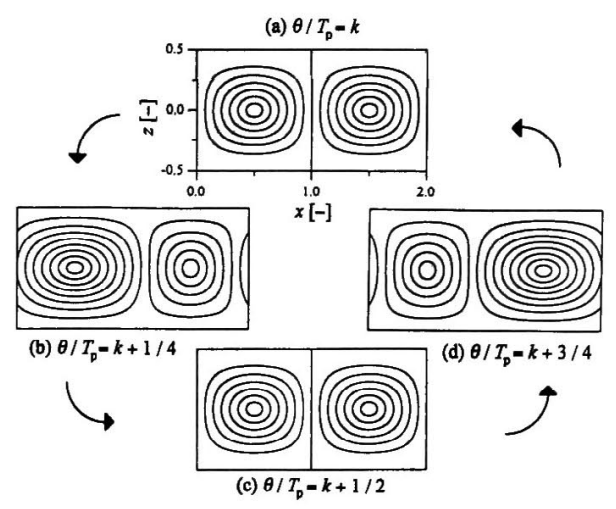

Fig. 5 Streamlines of a time dependent cellular flow

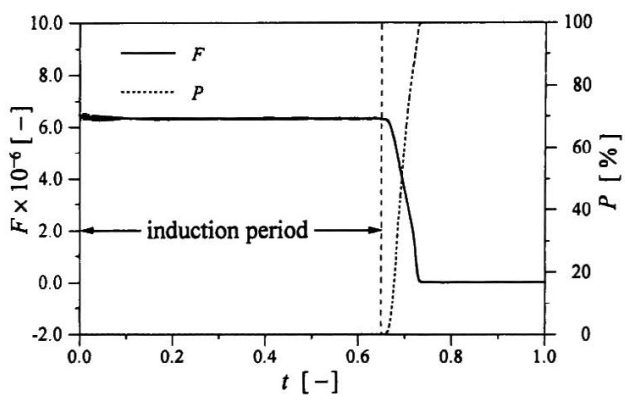

Fig. 6 Evaluation function $F$ and the ratio $P$ of converged $T_{j i}$

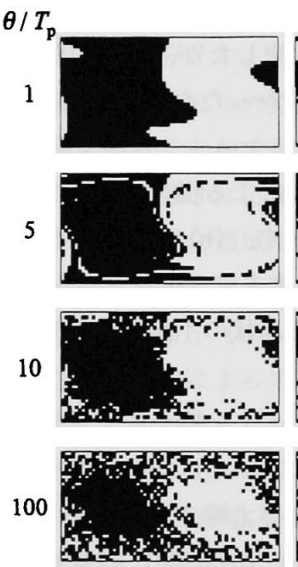

(a)
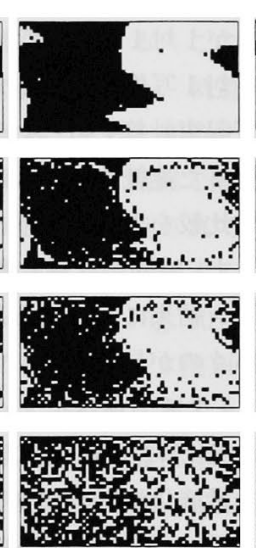

(b)
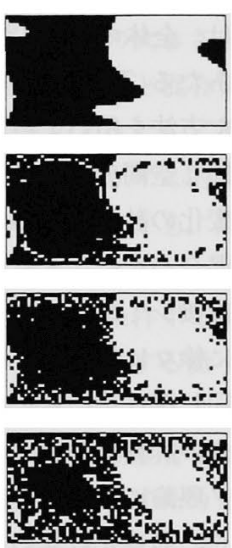

(c)
Fig. 7 Time variations of the mixing pattern with (a) direct simulation, (b) discrete mapping without the domain reduction method and (c) discrete mapping with the domain reduction method

算した.

\section{2. 計算結果および考察}

\section{1 離散写像による混合パターン}

解析を行う混合系として, Eqs. (12)，(13)で， $\varepsilon=0.1 ， \omega=1.0$ とした流れ場を仮定し, 左側セルを黒色, 右側セルを白色とした 初期着色パターンからの混合過程を考える.

この流れ場に対し, 1 对 1 写像を求める計算を行った. 系全体を 一つのドメインとし，1.2.4で述べたドメイン縮小法を用いなか った混合の計算結果を Figs. 6, 7 に示す. 微小七儿数は $N=64 \times$ 32 で，最適化計算のパラメーターは， $A=2,048(=N), \alpha=$ $0.001, \Delta=0.1$ とした. Fig. 6 の実線で示したように, 評価関数 $F$ は収束計算パラメータ $t$ の増加とともに減少し, 最終的には一定 


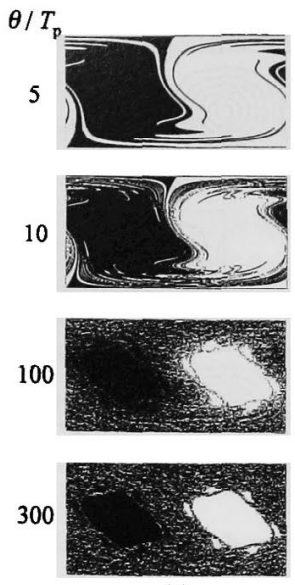

(a)
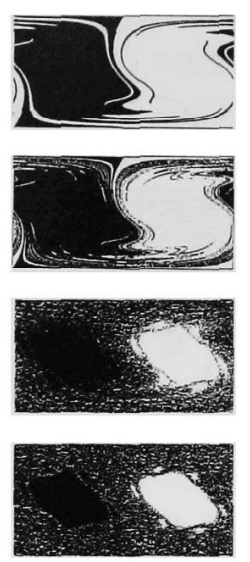

(b)
Fig. 8 Time variations of the mixing pattern with (a) direct simulation and (b) discrete mapping with the combined use of the domain reduction and the neuro-dynamics for combinational optimization

值に収束する. $t<0.65$ の誘導期間では, 写像行列の各成分 $T_{j i}$ の 值はほとんど変化しないように見えるが，その中の特定の成分だ けが徐々に増加する，やがて，写像行列の各列と各行からただ一 つ選ばれた成分だけが選択的に增加し，それに伴って $F$ の値が急 速に減少し始める. Fig. 6 の破線 $P$ は，全成分の中で 0 または 1 に収束したとみなせる $T_{j i}$ 成分数の割合を示している．1次計算 では, 全体の $99.51 \%$ が 1 对 1 写像に収束したが, 残りの $0.49 \%$ にあたる $T_{j i}$ 成分は 1 対 1 写像とならなかったため, 1.2 .3 に述 べた方法を用いて再度収束計算を行った。

同じ空間分解能で行った連続体モデルによる混合パターンの時 間変化の計算結果との比較を Fig. 7 に示す.（b）の離散写像によ る混合パターンを見ると, 時間の経過とともに, 外部の流体が(a) の直接シミュレーション結果に見られる島状の不良混合領域の内 部に徐々に侵入していくのが見られる.

同じ流れ系に対し，1.2.4で述べたドメイン縮小法を併用した 場合の計算結果を Fig. 7 (c)に示す.ただし，ニューラルネットワ 一ク理論による組合せ最適化法への切り替之時のドメインサイズ は 64 , 最適化計算のパラメー夕は $A=64, \alpha=0.001, \Delta=0.01$ と した.この場合は, 1 次計算だけで 1 对 1 を満足する写像行列が得 られた。評価関数 $F$ の収束值は, ドメイン分割をしなかった場合 はF=136.77であったのに対し，ドメイン分割した場合は $F=$ 103.95 に減少した. 混合パターンの時間変化も, 直接シミュレー ションによる結果の Fig. 7(a) によク近いものになっていること がわかる.

微小七ル数を $N=1,024 \times 512$ に増加させた場合の計算結果を Fig. 8 に示す.（a）は直接シミュレーション結果，（b）は離散写 像による計算結果である，ただし，後者の計算では組合せ最適化 法への切り替之時のドメインサイズを 64 , 最適化計算のパラメー ターを $A=64, \alpha=0.001, \Delta=0.01$ とした.このような大きな微 小セル数では, ドメイン䈹小法を併用しなければ計算を遂行する ことはできない，両者の混合パターンを比較すると， $\theta / T_{\mathrm{p}}=300$ に至るまでの全混合過程において, ほほ完全に一致していること がわかる.

Fig.9 は, 混合度の時間変化の比較である.ここで用いた混合度 は, 白色セルと黒色セルの境界線長さを基準とした混合度で, 左 側セルが黒色, 右側セルが白色の初期状態で 0 , 白色セルと黑色セ

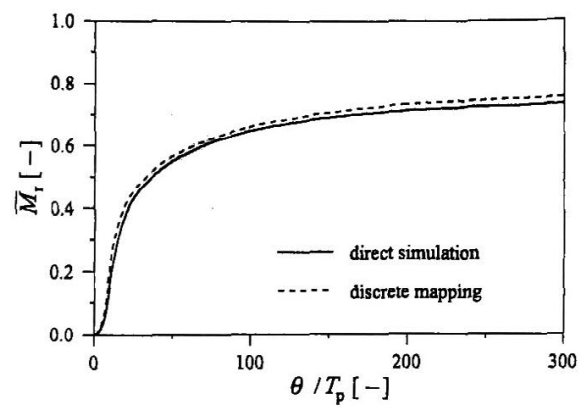

Fig. 9 Time variations of the relative mean mixedness $\bar{M}_{\mathrm{r}}$

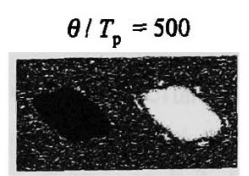

(a) $F=3393$

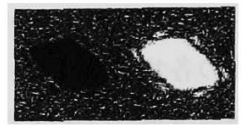

(b) $F=3517$

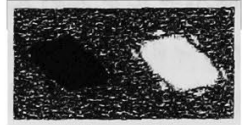

(c) $F=3637$

Fig. 10 Mixing patterns at $\theta / T_{\mathrm{P}}=500$. Domain sizes at switching time of the algorithms are (a) 64 , (b) 16 and (c) 1

ルが系全体にランダムに配置した状態で 1 となるように規格化さ れている (Appendix) (Inoue and Hirata, 2000). 離散写像と直 接シミュレーションによる混合度の経時変化はほぼ同じ值を示す が, 離散写像による混合度の方がわずかに大きい值を示す。これ は, 七ル中央部に位置する非混合領域を取り囲む小さな非混合領 域が, 少し浸食されて小さくなっているためと考えられる.この ように, 微小セル数を十分に大きくとれば, 1 对 1 離散写像を用い ても，混合パターンの時間変化を十分に精度よく表現できること がわかる.

\section{2 ドメインサイズが離散写像に及ぼす影翌}

1 対 1 の離散写像を得る方法として, ドメイン縮小法とニュー ラルネットワーク理論による組み合わせ最適化法を併用する方法 を 1.2 節に記した. 原理的には, 最後のドメインに含まれる微小七 儿数が1になるまでドメイン縮小法を適用して, 写像行列を決め ることができる、この場合、ニューラルネットワーク理論による 組み合わせ最適化法は用いない。

本節では, 1 対 1 写像構成の計算におけるドメイン縮小法から ニューラルネットワーク理論による組み合わせ最適化法への切り 換え時のドメインサイズが, 得られる離散写像の精度に及ぼす影 響について検討する。

Fig. 10 は, 微小セル数 $N=1,024 \times 512$ とした場合の離散写像 により得られた $\theta / T_{\mathrm{p}}=500$ における混合パターンである。ただ し，ドメイン縮小法からニューラルネットワーク理論による組み 合わせ最適化法へ切り換えたときの各ドメインに含まれる微小七 ル数が，（a）では 64，（b）では 16 であり，(c) は最後までニュー ラルネットワーク理論による組み合わせ最適化法を用いなかった 場合である。混合パターンを見る限り，組み合わせ最適化法を用 いても用いなくともその差はほとんどないように見える。しかし， 1.2 .1 で導入した写像の有効性を表す評価関数 $F$ の值をみると, 


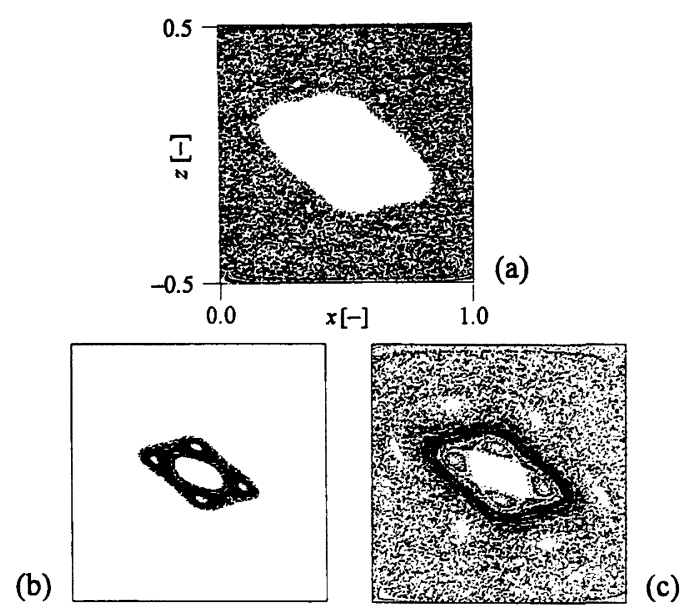

Fig. 11 Subgrids belonging to three representative orbits that cover (a) the chaotic mixing region, (b) the shear mixing region and $(c)$ both of them

(a) で3,393, (b) で3,517, (c) で3,637となり, ニューラルネ ットワーク理論による組み合わせ最適化法を用いた方がより小さ な值を示す．また, 組み合わせ最適化法への切り換之時に各ドメ インに含まれる微小七ル数が多いほど, 評価関数 $F$ の值が小さく なっている.これより，ドメイン縮小法にニューラルネットワー ク理論による組み合わせ最適化法を併用することにより，より精 度の高い 1 对 1 写像が得られることがわかる.ドメイン縮小法か ら組み合わせ最適化法への切り換之時のドメインサイズは大きい 方がよいが,ドメインサイズが 64 を超えると 1 对 1 写像が得にく くなり，計算時間も急速に増加する傾向がみられた。

\section{3 離散写像法の問題点}

前報 (Inoue and Hirata, 1999, 2000) やFig.10に示したよう に, 本解析に用いた流動条件 $\varepsilon=0.1, \omega=1.0$ では, カオス的に混 合が行われる良混合領域と, 剪断混合が支配的な不良混合領域が 共存し, それらが準周期軌道で構成された KAM 曲線により隔て られた最終混合パターンが得られる. 本解析モデルのように, 流 れ系全体を有限個の微小七ルに分割し，それらの間の 1 対 1 写像 を基にした決定論的な離散写像モデルでは，カオス的運動や準周 期的運動のような非周期的運動を表現することはできない.この モデルでは，すべての流体粒子は閉じた周期軌道を描き，各周期 軌道に含まれる微小七ルの数がその軌道の周期に比例する。した がって，もともとカオス的な混合領域内を非周期的に運動してい た流体粒子は, 離散写像モデルでは非常に長い周期軌道を描くと 予想されるが，それは後に示すように計算でも確かめることがで きる.

この離散写像モデルで非周期軌道や準周期軌道を表現すること は不可能であるが, 周期軌道を正確に表現することも極めて困難 である.写像時の 1 セルの位置のずれが, 本来閉じた軌道を開いた 軌道に変えてしまう可能性があるためである，同様の情況が, 準 周期軌道近傍の運動を離散写像に変換する場合にも生じる。準周 期軌道の外側にある流体粒子の軌道は, 本来その準周期軌道を越 えて内側に入り込むことはできない.しかし，離散写像の構成法 が悪い場合には，内部に入り込む軌道となる可能性がある。この 場合，準周期軌道の外側の流体粒子が内側領域に進入することに なるため, 離散化しない場合と離散化した場合の長時間経過後の 混合パターンは大きく異なる可能性がある.

離散写像モデルではすへての流体粒子が周期軌道を描くのに対
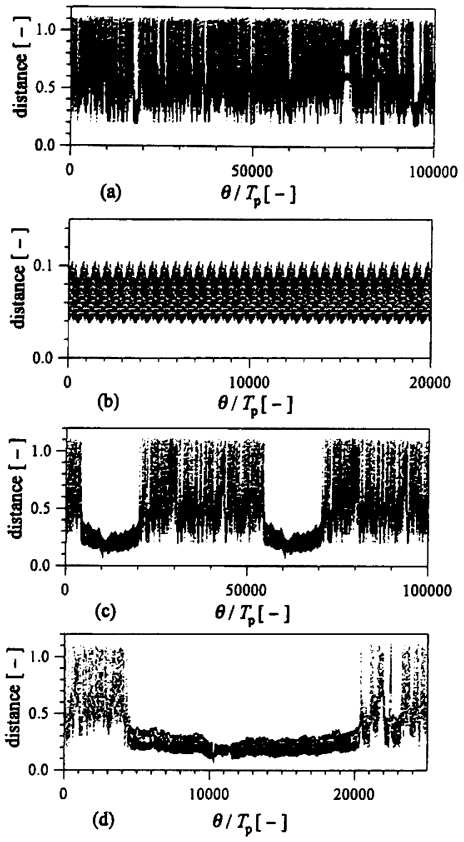

Fig. 12 Time variation of the distance between a fluid particle and the center of the left cell. Initial positions of the fluid particle are (a) $x \approx 0.317, z \approx 0.433$, (b) $x \approx 0.580$, $z \approx-0.038$ and $($ c) $x \approx 0.051, z \approx-0.265$

応して，混合場に含まれる全微小セルをそれが属する微小セルご とにグループ分けすることができる．このグループの大きさとそ れに属する微小七ルの空間配置から, 軌道周期の長さと混合領域 の範囲を知ることができる．それと同時に，このようにして得ら れたグループ分けにより，KAM 曲線で隔てられるカオス的混合 領域と剪断的混合領域が正しく分別されているかどうかを, 離散 写像の精度を判定する基準として利用することができる.

Fig.11の（a)，(b)，（c）は，Fig. 10（a）と同じ条件下で計算 された離散写像によって得られた， 3 種類の軌道に属する微小七 ルを示したものある（a）の軌道に属する流体粒子はカオス混合 領域内だけを，(b) の軌道に属する流体粒子は剪断的混合領域内 だけを動き回り，離散写像においても，KAM曲線を隔てたカオス 的混合領域と剪断的混合領域が分離されていることがわかる. 他 方，(c)ではカオス的混合領域に属する流体粒子が, KAM 曲線領 域を越之て剪断的混合領域にまで入り込んでいる.これは, KAM 曲線を構成する準周期軌道に対応する離散写像の軌道が，その外 側と内側をそれぞれ回る軌道の貫通を阻止する役割を果たしてい ないためと考えられる.

Fig. 12 は 1 個の流体粒子の運動を, 左側の渦の中心 $(x=0.5$, $z=0.0 ）$ からの距離の時間変化として表した図である. Figs. 12 (a)，(b)，(c) は，それぞれ Figs.11(a)，(b)，(c) で示した 軌道に対応している.（d）は，(c) の一部分 $\left(0 \leq \theta / T_{\mathrm{p}} \leq 25,000\right)$ を拡大した図である。

Figs. $12(\mathrm{a})$ ，(b) のように流体粒子がカオス的混合領域内だけ を動き回る場合(初期位置； $x \approx 0.317, z \approx 0.433$ ), および剪断的 混合領域内だけを移動する場合（初期位置： $x \approx 0.580, z \approx-$ 0.038）では，左側の渦の中心との距離はそれぞれ 0.2 から 1.2, および 0.04 から 0.1 の範囲内で変動する．また，(a)，(b) のそ れぞれの軌道の周期は $74,451\left[\theta / T_{\mathrm{p}}\right], 9,498\left[\theta / T_{\mathrm{p}}\right]$ である。こ れより，カオス的混合領域内の軌道は剪断的混合領域内の軌道に 比へはるかに長い周期をもつことがわかる。 
$x \approx 0.051, z \approx-0.265$ を初期位置とする流体粒子の運動を表し た Figs. 12 (c)，(d)では，大きな振幅の変動で表されたカオス的 混合領域を動き回る長い期間と, 小さな振幅の変動で示された KAM 曲線近傍を準周期的軌道に近い運動をする短い期間とが交 互に現れ，その周期は 50,320[ $\left.\theta / T_{\mathrm{p}}\right]$ である. Fig. $12(\mathrm{~d})$ におい て, 準周期軌道に近い運動を行う期間 $\theta / T_{\mathrm{p}}=4,300 \sim 20,500$ の 内, $\theta / T_{\mathrm{p}} \approx 11,000$ 付近のごく短い期間だけ流体粒子は KAM 曲 線領域よりも内部の領域に侵入する.

このように，力オス的混合領域に属する流体粒子が剪断的混合 領域内に入り込む軌道では, カオス的混合領域を運動する期間に 比へてて流体粒子が KAM 曲線付近の軌道にトラップされている 期間が短く，また，トラップ軌道から離れて内部領域に侵入する 期間はさらに短い.このため, Fig. 10 に示した $\theta / T_{\mathrm{p}}=500$ 程度の 混合時間では, KAM 曲線を越える軌道は混合パターンに重大な 影響を及ぼさなかったと考えられる.この意味で, Fig. 11 のよう な混合領域の分別は, 離散写像の精度を調べる最も厳しい判定条 件であると言える. 実際, カオス的混合領域と内部の剪断混合領 域の分離は，離散写像構成時のわずかな条件の違いに敏感に影響 され，それらをコントロールするだけの有効かつ安定した離散写 像の構成法や条件はまだ見いだされていない.

\section{結言}

時間的に周期変動する層流流れ場における混合パターンの時間 変化を表現する, 新しい離散写像モデルを開発した.

1）時間と位置座標および濃度場を離散化することにより，1 周期間の流体粒子の位置変化を写像行列で, 混合パターンを ベクトルで表現した。これにより混合パターンの時間変化を， 写像行列に作用された混合パターンベクトルの回転運動とし て表現することが可能になった。

2）流体粒子の写像行列を流れ場の速度ベクトルから構成する アルゴリズムを開発した。ドメイン縮小法とニューラルネッ トワーク理論を基にした組み合わせ最適化法を併用すること により，高精度の写像行列が高速で計算できることを示した。

3）離散写像モデルを用いた計算結果は, 通常の連続体として の取り扱いによるシミュレーション結果とほぼ同じ混合パタ ーンの時間変化を示した。

4）ドメイン縮小法から組合せ最適化法の切り替之時のドメイ ンサイズが大きいほど，より精度の高い 1 对 1 写像が得られ る.ただし,ドメインサイズが 64 を越えると 1 対 1 写像が得 にくくなり，計算時間も急速に增加する.

5）このモデルでは, 系内の流体運動を有限個の流体粒子の写 像として表現したため, 全ての流体粒子の運動は有限の長さ をもつ周期的運動となる. そのため, カオス的な運動や準周 期的運動のような非周期運動を表現することはできず, 非常 に長い周期をもつ周期的運動として表現される.

\section{Appendix}

混合状態を定量的に評価する量として, 初期混合度 $\bar{M}(0)$ と白色セルと黒 色セルがランタムに配置した場合の混合度 $\bar{M}_{\text {rand }}$ を用いて規格化した時刻 $\theta$ における相对平均混合度 $\bar{M}_{\mathrm{r}}(\theta)$ を用いた (Inoue and Hirata, 2000).

$$
\bar{M}(\theta)=\{\bar{M}(\theta)-\bar{M}(0)\} /\left\{\bar{M}_{\mathrm{rand}}-\bar{M}(0)\right\}
$$

ただし，平均混合度 $\bar{M}(\theta)$ は次式で定義する。

$$
\bar{M}(\theta)=\frac{1}{2 I_{\max }\left(2 J_{\max }-1\right)} \sum_{i=1}^{I_{\max }} \sum_{J=1}^{J_{\max }}\left\{C_{I J}: J+1, J(\theta)\right.
$$

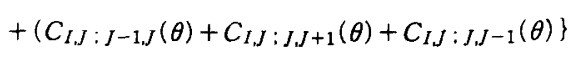

ここで, $C_{I, J ; I^{\prime}, J^{\prime}}(\theta)$ は, 時刻 $\theta$ における微小セル $[I, J]$ とそれに隣接 する $[I \pm 1, J \pm 1]$ を占める流体の色が同しであれば 0 , 異なれば 1 となる 2 值変数である. また, $I_{\max }$ と $J_{\max }$ は, それぞれ $x$ 方向と $z$ 方向に並んた微 小セルの個数である $\left(N=I_{\max } \times J_{\max }\right)$.

[謝 辞] 本研究の一部は文部省科学研究費補助金萌芽的研究（課題 番号 11875166）により行われたことを記して謝意を表します.

\section{Nomenclature}

$A$ = weighted parameter in Eq. (8)

$C_{I, J ; I^{\prime}, I^{\prime}}=$ binary variable expressing color difference between the subcells $[I, J]$ and $\left[I^{\prime}, J^{\prime}\right]$

$D_{j i}{ }^{*}=$ parameter $\left(\equiv(1-\alpha) d_{j i}{ }^{*}-\alpha S_{j i}{ }^{*}\right)$

$d_{j i}=$ distance $\left(\equiv\left|\boldsymbol{g}_{j}-\boldsymbol{r}_{i}\right|\right)$

$[-]$

$d_{j i}{ }^{*}=$ distance factor $\left(\equiv d_{j i} /\left(d_{j i}\right)_{\text {ave }}\right)$

$[-]$

$F=$ evaluation function

$[-]$

$f_{j i}=$ variable defined by Eq. $(11)$

$[-]$

$\boldsymbol{g}_{j}=$ representative position vector of a fluid element in the subcell $j$

$h$ =effective increment of $t \quad[-]$

$I \quad=$ lateral subcell number $\quad[-]$

$i \quad=$ integer $(1,2, \cdots, N) \quad[-]$

$J \quad=$ vertical subcell number $\quad[-]$

$j \quad=$ integer $(1,2, \cdots, N) \quad[-]$

$K$ =figure indicating a fluid kind $\quad[-]$

$k$ =integer $(1,2, \cdots, N) \quad[-]$

$\bar{M}=$ mean mixedness based on short-range correlation defined by Eq. (A.2)

[-]

$\bar{M}_{\mathrm{r}}=$ relative mean mixedness based on short-range correlation defined by Eq. (A.1) [-]

$N=$ total number of subcells in the flow field $\quad[-]$

$n$ =integer [-]

$p_{i}=i$ th component of vector $\boldsymbol{P} \quad[-]$

$\boldsymbol{P}=$ mixing pattern vector $[-]$

$P \quad=$ ratio of number of converged elements $T_{j i} \quad[-]$

$\boldsymbol{r}_{i}=$ center position vector of subcell $i \quad[-]$

$S_{j i}=$ area ratio $[-]$

$S_{j i}{ }^{*}=$ area ratio factor $\left(\equiv S_{j i} /\left(S_{j i}\right)_{\mathrm{ave}}\right)$

$T_{\mathrm{p}}=$ period of perturbative flow $[-]$

$\boldsymbol{T}_{\Delta \theta}=$ mapping matrix during $\Delta \theta \quad[-]$

$T_{j i}=(j, i)$ element of mapping matrix $\boldsymbol{T}_{T_{\mathrm{p}}} \quad[-]$

$t \quad=$ variable in the dynamical system defined by Eq. (8) [-]

$x$ = coordinate [-]

$z$ = coordinate [-]

$\alpha \quad=$ parameter used in the defined $D_{j i}{ }^{*} \quad[-]$

$\Delta=$ maximum increment of $t \quad[-]$

$\varepsilon \quad=$ amplitude of perturbative flow $[-]$

$\theta=$ time $[-]$

$\omega=$ angular frequency of perturbative flow $\quad[-]$

$\psi=$ total stream function [-]

$\psi_{0}=$ stream function of unperturbed flow $[-]$

$\psi_{1} \quad=$ stream function of perturbative flow [-]

〈Subscripts〉

ave $=$ average

$\max =$ maximum

rand $=$ random 


\section{Literature cited}

Abid, M., C. Xuereb and J. Bertrand; "Modeling of the $3 \mathrm{D}$ Hydrodynamics of 2-Blade Impellers in Stirred Tanks Filled with a Highly Viscous Fluid," Can. J. Chem. Eng., 72, 184-193 (1994)

Chella, R. and J. M. Ottino ; "Conversion and Selectivity Modifications Due to Mixing in Unpremixed Reactors," Chem. Eng. Sci., 39, 551 -567 (1984)

Fox, R. O. and J. Villermaux ; "Unsteady-State IEM Model Numerical Simulation and Multiple-Scale Perturbation Analysis near Perfect -Micromixing Limit," Chem. Eng. Sci., 45, 373-386 (1990)

Funahashi, H., H. Harada, H. Taguchi and T. Yoshida; "Circulation Time Distribution and Volume of Mixing Regions in Highly Viscous Xanthan Gum Solution in a Stirred Vessel," J. Chem. Eng. Japan, 20, 277-282 (1987)

Hopfield, J. J. and D. W. Tank; “"'Neural” Computation of Decisions in Optimization Problems," Biol. Cybern., 52, 141-152 (1985)

Inoue, Y. and Y. Hirata; "Numerical Analysis of Chaotic Mixing in Plane Cellular Flow I, Formation Mechanism of Initial Mixing Pattern and Micro Cellular Pattern," Kagaku Kogaku Ronbunshu,
25, 294-302 (1999)

Inoue, Y. and Y. Hirata ; "Numerical Analysis of Chaotic Mixing in Plane Cellular Flow II, Mixedness and Final Mixing Pattern," Kagaku Kogaku Ronbunshu, 26, 31-39 (2000)

Koh, S. T., S. Hiraoka, I. Yamada, Y. Tada, T. Aragaki and T. Takahashi; "Jet Mixing of Liquids in a Rotating Cylindrical Vesssel," J. Chem. Eng. Japan, 22, 611-615 (1987)

Mann, R., R. A. Williams, T. Dyakowski, F. J. Dickin and R. B. Edwards; "Development of Mixing Models Using Electrical Resistance Tomography," Chem. Eng. Sci., 52, 2073-2085 (1997)

Sheikh, F. and R. D. Vigil ; "Simulation of Imperfect Micromixing for First-Order Adiabatic Reactions: the Coalescence-Dispersion Model," Chem. Eng. Sci., 53, 2137-2142 (1998)

Tanguy, P. A., R. Lacroix, F. Bertland, L. Choplin and E. Brito de la Fuente; "Finite Element Analysis of Viscous Mixing with a Helical Ribbon-Screw Impeller," AIChE J., 38, 939-944 (1992)

Uesaka, Y.; Nyurokonpyuthingu no Sugakuteki Kiso, p. 84-85, Kindai Kagakusya, Tokyo, Japan (1993)

Zwietering, Th. N. ; "A Backmixing Model Describing Micromixing in Single-Phase Continuous-Flow Systems," Chem. Eng. Sci., 39, 1765 $-1778(1984)$

\title{
Modeling of Fluid Mixing Process Using Discrete Mapping - Construction of Discrete Mapping with Combinational Optimization Based on Neural Network Theory -
}

\author{
YUJI TACHIBANA, YOSHIRO INOUE and YUSHI HIRATA
}

\author{
Department of Chemical Science and Engineering, Graduate School of Engineering Science, \\ Osaka University, Toyonaka 560-8531
}

Key words: fluid mixing, mixing model, discrete mapping, mixing pattern vector, neural network
theory.

The progress of a mixing pattern is calculated with the knowledge of displacement of fluid particles obtained by integrating the velocity vectors with respect to time. In time-periodic flow, especially the mixing pattern at a discrete time whose interval is equal to multiple periods is able to be estimated with the knowledge of the fluid motion during only one period. In this study, the new discrete model is proposed, and this model enables expression the mixing process in the time-periodic laminar flow. Both the independent variables, time and space, and the dependent variable, concentration, are digitized there. As a result, continuous fluid motion is discretely treated, and the change in mixing pattern is expressed as rotation of a vector representing the mixing pattern. A new algorithm is developed in order to reproduce precisely the fluid motion during one period. In this algorithm, the combinational optimization method based on the neural network theory is used together with the domain reduction method. By use of the discrete model, the progress of mixing pattern in laminar flow is able to be calculated fast and precisely. 